\title{
Ice sheet mass loss caused by dust and black carbon accumulation
}

\author{
T. Goelles ${ }^{1,2}$, C. E. Bøggild ${ }^{3}$, and R. Greve ${ }^{4}$ \\ ${ }^{1}$ The University Centre in Svalbard (UNIS), Longyearbyen, Norway \\ ${ }^{2}$ Norwegian University of Life Sciences (NMBU), Aas, Norway \\ ${ }^{3}$ Arctic Technology Centre, Technical University of Denmark, Kgs. Lyngby, Denmark \\ ${ }^{4}$ Institute of Low Temperature Science, Hokkaido University, Sapporo 060-0819, Japan \\ Correspondence to: T. Goelles (thomas.golles@unis.no, thomas.goelles@gmail.com)
}

Received: 31 March 2015 - Published in The Cryosphere Discuss.: 23 April 2015

Revised: 18 August 2015 - Accepted: 24 August 2015 - Published: 22 September 2015

\begin{abstract}
Albedo is the dominant factor governing surface melt variability in the ablation area of ice sheets and glaciers. Aerosols such as mineral dust and black carbon (soot) accumulate on the ice surface and cause a darker surface and therefore a lower albedo. The darkening effect on the ice surface is currently not included in sea level projections, and the effect is unknown. We present a model framework which includes ice dynamics, aerosol transport, aerosol accumulation and the darkening effect on ice albedo and its consequences for surface melt. The model is applied to a simplified geometry resembling the conditions of the Greenland ice sheet, and it is forced by several temperature scenarios to quantify the darkening effect of aerosols on future mass loss. The effect of aerosols depends non-linearly on the temperature rise due to the feedback between aerosol accumulation and surface melt. According to our conceptual model, accounting for black carbon and dust in future projections of ice sheet changes until the year 3000 could induce an additional volume loss of $7 \%$. Since we have ignored some feedback processes, the impact might be even larger.
\end{abstract}

\section{Introduction}

The Greenland ice sheet contributes to sea level rise through dynamic processes and surface mass balance (SMB). After the year 2009, about $84 \%$ mass loss of the Greenland ice sheet was due to a reduced SMB (Enderlin et al., 2014). The SMB is the net balance between snow accumulation and ablation consisting of melt and sublimation of snow and ice. Therefore calculations of SMB depend on the accuracy of snowfall and ablation. Ablation is largely controlled by nearsurface temperature and absorbed short-wave radiation. Surface albedo and the amount of incident radiation controls the portion of absorbed short-wave radiation (e.g. van Angelen et al., 2012; Bougamont et al., 2005; Tedesco et al., 2011).

In the Fifth Assessment Report (AR5; IPCC, 2013), ablation was computed by energy balance models (EBMs) and with the positive-degree-day (PDD) method, which does not explicitly include surface albedo. Regional climate models with energy balance models produced a $14-31 \%$ higher sea level rise contribution from the Greenland ice sheet than models using PDD (Goelzer et al., 2013) because PDD can not account for the positive feedback of albedo to nearsurface temperature. Surface albedo implementations vary through the different EBMs considered in the AR5. The surface albedo is primarily determined by whether the surface consists of snow or ice and by the optical properties of the surface. All the EBMs in the AR5 used for sea level rise predictions have rather sophisticated snow albedo schemes, while the ice albedo is often constant in space and time (e.g. Mernild et al., 2010; Rae et al., 2012).

Surface albedo is determined by the optical properties of the surface, the angle of incidence of downward radiation and the ratio of direct to diffuse radiation. The optical properties of ice are mainly determined by the specific surface area of ice (that results from the combined effect of air bubbles, cracks, etc.). In addition, the optical properties are altered by the content of liquid water and impurities (Cuffey and Paterson, 2010). These impurities consist of aerosols such as mineral dust and black carbon (BC) and impurities related to biological activity. Dust makes up most of the im- 


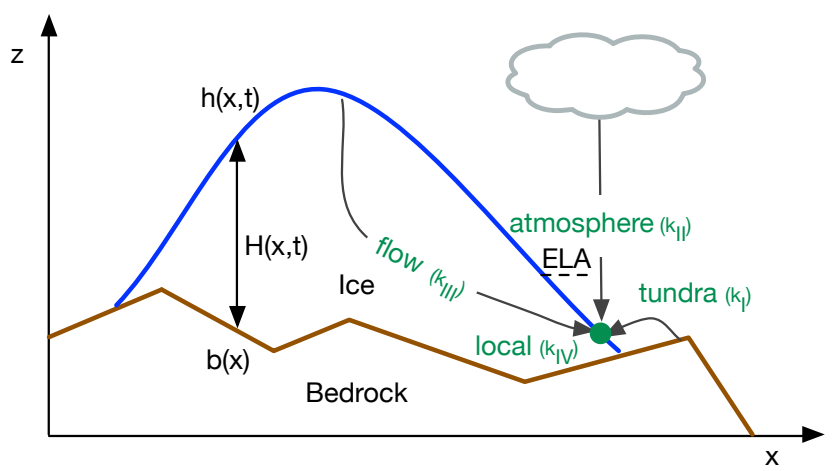

Figure 1. Cross section through an ice sheet: the different mechanisms of aerosol transport to the ablation zone. ELA stands for equilibrium line altitude, $b$ is the (fixed) bedrock elevation, $h$ the ice surface elevation and $H$ the ice thickness.

purity mass on ice (Bøggild et al., 2010; Takeuchi et al., 2014), but BC has a higher effect on albedo per mass (Warren and Wiscombe, 1980). The darkening effect and dynamics of biological-related impurities remain to be quantified (Stibal et al., 2012; Yallop et al., 2012).

$\mathrm{BC}$ is a carbonaceous material which strongly absorbs visible light and is formed primarily in flames (Bond et al., 2013). Ice core data from Greenland revealed higher concentrations in ice dated younger than 1850 (McConnell et al., 2007) due to increased emissions after the industrial revolution. BC concentrations decreased back to almost preindustrial levels around 1950 due to successful mitigation in North America, which was found to be the source of BC in Greenland during that period. In contrast to that, $\mathrm{BC}$ emissions in Asia have been rising since the year 2000 (Lei et al., 2011; Lu et al., 2011).

Asia was found to be the main source of dust during the last glacial (Biscaye et al., 1997). During glacials the dust concentration in ice is $10-100$ times higher than during interglacials such as the current Holocene (Steffensen, 1997). Ice from the last glacial is found in the deeper parts of the Greenland ice sheet (MacGregor et al., 2015) and therefore acts as a reservoir for large amounts of dust (Reeh et al., 1991; Bøggild et al., 1996).

Dust and BC are transported with the ice flow towards the ablation zone, where melt releases the particles. Over time the impurities from melt-out and atmospheric deposition accumulate, which enhances melt and therefore causes more particles to be released. This positive feedback is currently unquantified and not included in the AR5 sea level rise experiments.

In this study, we investigate the impact on ice sheet volume caused by the darkening effect of dust and $\mathrm{BC}$ on the ice surface of the Greenland ice sheet. We introduce a new model framework which includes transport, melt-out and accumulation of aerosols and its effect on ice albedo coupled to the SMB and ice dynamics. This model is then applied to

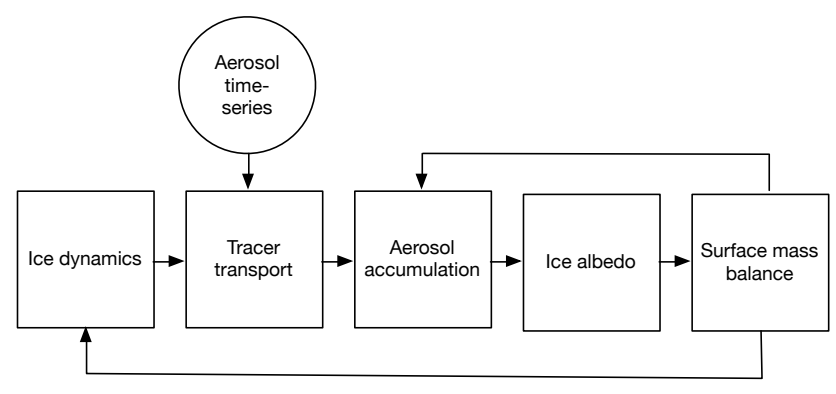

Figure 2. Model framework: the ice dynamics component delivers velocity and ice sheet dimensions to the tracer transport module. An aerosol time series in conjunction with the tracer transport conveys englacial aerosol concentrations to the accumulation module. The SMB module delivers snow depth and melt rates to the accumulation module, which calculates dust and BC amounts separately in the snowpack and on the ice surface. These results are then fed into the ice albedo module which is used by the SMB component (based on a simplified energy balance). The SMB is then fed back into the ice dynamics module.

a simplified geometry and forced by future climate scenarios until the year 3000 .

\section{Model description}

\subsection{Model framework and set-up}

Aerosols reach the ablation zone by four different mechanisms (Fig. 1): via direct atmospheric deposition from local sources $\left(k_{\mathrm{I}}\right)$, by large-scale transport $\left(k_{\mathrm{II}}\right)$ or by melt-out of englacial particles which have been transported via ice flow $\left(k_{\mathrm{III}}\right)$. Local production $\left(k_{\mathrm{IV}}\right)$ is only relevant for microbiological activity and is 0 for dust and BC considered in this study. The atmospheric contribution $\left(k_{\mathrm{II}}\right)$ and input from the surrounding tundra $\left(k_{\mathrm{I}}\right)$ are prescribed and constant in the simulations. Melt-out of aerosols $\left(k_{\mathrm{III}}\right)$ requires, besides the SMB, the near-surface concentration of englacial aerosols $\left(\left[\iota_{n}\right.\right.$,englacial $\left.\left.)\right]\right)$. This is calculated via a tracer transport module which depends on the aerosol time series, velocities and ice sheet dimensions (Fig. 2).

Aerosol accumulation, ice albedo and surface mass balance are presented in detail in Goelles and Bøggild (2015), and therefore their description is kept to a minimum in the following sections. The common quantities and physical constants are listed in Table 1. The model is realised in Mathematica (version 10; Wolfram Research, Inc., 2014) using self-coded solvers for the differential equations.

\subsection{Ice dynamics}

We employed the shallow ice approximation in plane strain, that is, only the vertical $x-z$ plane is considered. The corresponding finite difference discretisation is described in detail by Greve and Blatter (2009). The ice thickness equa- 
Table 1. Standard physical parameters and constants.

\begin{tabular}{|c|c|c|c|}
\hline Symbol & Short description & Value & Unit \\
\hline$x_{\mathrm{su}}$ & Location of the summit & 750 & $\mathrm{~km}$ \\
\hline$T_{+, \mathrm{su}}$ & Temperature in summer at summit & -8 & ${ }^{\circ} \mathrm{C}$ \\
\hline$S_{T}$ & Horizontal temperature gradient & $1.67 \times 10^{-2}$ & $\mathrm{~K} \mathrm{~km}^{-1}$ \\
\hline$\rho_{\text {ice }}$ & Density of ice & 910 & $\mathrm{~kg} \mathrm{~m}^{-3}$ \\
\hline$\rho_{\mathrm{W}}$ & Density of water & 1000 & $\mathrm{~kg} \mathrm{~m}^{-3}$ \\
\hline $\mathcal{A}$ & Seconds per year & 31556926 & - \\
\hline$r_{\max }$ & Refreezing fraction & 0.6 & - \\
\hline$t^{t} \bigcirc$, start & Start of summer & 121 & day of the year \\
\hline$t^{\mathrm{O}}$, end & End of summer & 244 & day of the year \\
\hline 5 & Temperature slope & 0.2 & $\mathrm{~K}_{\text {day }}{ }^{-1}$ \\
\hline$\lambda$ & Long-wave radiation coefficient & 10 & $\mathrm{~W} \mathrm{~m}^{-2} \mathrm{~K}^{-1}$ \\
\hline$c$ & Short-wave radiation and sensible heat flux constant & -55 & $\mathrm{~W} \mathrm{~m}^{-2}$ \\
\hline$L_{\mathrm{m}}$ & Latent heat for melting of ice & 334000 & $\mathrm{Jkg}^{-1}$ \\
\hline$d_{\text {eff }}$ & Effective depth of ice & 5 & $\mathrm{~m}$ \\
\hline$r_{\text {ice }}$ & Reduction fraction, ice & 0.001 & day $^{-1}$ \\
\hline$r_{\text {snow }}$ & Reduction fraction, snow & 0 & - \\
\hline- & Dust-to-BC conversion factor & $1 / 200$ & - \\
\hline$\Delta t_{\mathrm{dyn}}$ & Ice dynamics time step for the spin-up & 50 & years \\
\hline$\Delta t_{\mathrm{dyn}}$ & Ice dynamics time step for the experiments & 1 & year \\
\hline$\Delta t_{\mathrm{SMB}}$ & SMB and accumulation time step & 1 & day \\
\hline$T_{\mathrm{b}}^{\prime}$ & Basal temperature relative to pressure melting & -2 & ${ }^{\circ} \mathrm{C}$ \\
\hline $\mathcal{F}_{\text {ice }}$ & Active fraction for dust and $\mathrm{BC}$ on ice & 0.5 & - \\
\hline$\alpha_{\text {snow, wet }}$ & Wet snow albedo & 0.6 & - \\
\hline$\alpha_{\text {snow, dry }}$ & Dry snow albedo & 0.8 & - \\
\hline$d_{\text {crit }}$ & Critical snow depth & 0.05 & m w.e. \\
\hline$k_{\mathrm{II}, \mathrm{BC}}$ & Atmospheric input of $\mathrm{BC}$ & $6.34196 \times 10^{-7}$ & $\operatorname{ngs}^{-1}$ \\
\hline$k_{\text {II,dust }}$ & Atmospheric input of dust & 0.3 & $\operatorname{ngs}^{-1}$ \\
\hline$\hat{S}$ & Specific surface area of ice & 2 & $\mathrm{~cm}^{2} \mathrm{~g}^{-1}$ \\
\hline
\end{tabular}

tion is solved by an implicit scheme (e.g Greve and Calov, 2002). A terrain-following coordinate transformation is used in order to explicitly compute surface values. These are required for the tracer transport in order to calculate the englacial aerosol concentration close to the surface and ultimately ice albedo values. Basal sliding is implemented with a Weertman-type sliding law including sub-melt sliding (Greve, 2005).

\subsection{Tracer transport}

Dust and $\mathrm{BC}$ concentrations are indirectly derived from the time of deposition $t_{\mathrm{d}}$ and the aerosol time series (see next section). Besides the time $t_{\mathrm{d}}$, also the $x$ coordinate of deposition $x_{\mathrm{d}}$ is calculated via a semi-Lagrangian transport scheme based on Clarke and Marshall (2002). The scheme provides both $t_{\mathrm{d}}$ and $x_{\mathrm{d}}$ as functions of $(t, x, z)$. It has advanced stability compared to Eulerian advection while still using a regular grid. The scheme is common in atmospheric models and has been used before in ice sheet models for $\delta^{18} \mathrm{O}$ transport (Clarke and Marshall, 2002; Clarke et al., 2005; Lhomme et al., 2005; Lhomme, 2004; Goelles et al., 2014). Especially the indirect method is suited for discontinuous data such as aerosol concentration while still using a coarse vertical resolution. At each grid point a back trajectory is calculated based on the velocity field from the ice dynamics module. Here we use the first-order backtracking (Clarke and Marshall, 2002; Clarke et al., 2005; Lhomme et al., 2005; Lhomme, 2004) for simplicity and efficiency, knowing that this method has its limitations close to the margin (Goelles et al., 2014) (see discussion in Sect. 5.2).

\subsection{Aerosol time series}

The aerosol concentration $\left[\iota_{\mathrm{n}}\right.$,englacial $]$ of every grid point can be derived from the aerosol time series $f\left(t_{\mathrm{d}}\right)$ and the depositional time $t_{\mathrm{d}}(t, x, z)$ via the relationship

$\left[\iota_{\mathrm{n}, \text { englacial }}(t, x, z)\right]=f\left(t_{\mathrm{d}}(t, x, z)\right)$.

Data from ice cores with an established age-depth model are required for the right-hand side of Eq. (1). A comparison between the NGRIP and NEEM ice cores (Bigler, 2012) of Greenland showed very similar results in the two cores although they are more then $350 \mathrm{~km}$ apart. Therefore, we use only the information of one ice core for the whole ice sheet, and $f$ in Eq. (1) has no explicit dependence on $x$. The aerosol 

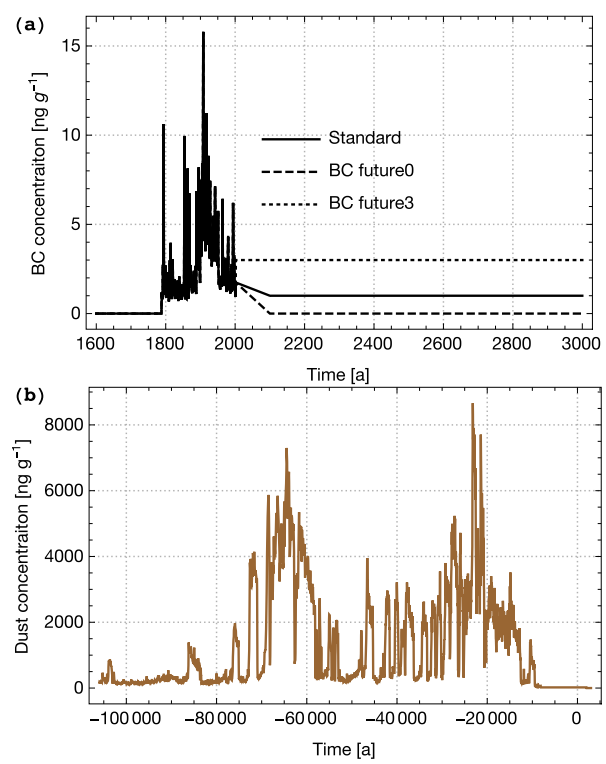

Figure 3. Aerosol time series of (a) black carbon (BC) and (b) dust. (a) The standard BC time series consists of ice core data by McConnell et al. (2007) and projections based on Bauer et al. (2013) with two additional trajectories of the future. In the period before data are available the $\mathrm{BC}$ concentration is set to 0 . (b) The dust concentration from NGRIP (Ruth, 2007), where the missing Holocene period (after $-8 \mathrm{ka}$ ) is assigned a constant value of $20 \mathrm{ng} \mathrm{g}^{-1}$, and a value of 0 is assumed after the year 2000 .

time series in Fig. 3 are extended beyond the data range in order to allow simulations until the year 3000 .

\subsection{Aerosol accumulation}

The accumulation module handles both bulk BC and dust content of the snowpack and the mass per area on the ice surface. It is described in detail in Goelles and Bøggild (2015). Aerosols accumulate in the snowpack from sources $k_{\mathrm{I}}$ and $k_{\mathrm{II}}$ and are released onto the ice surface as the snow disappears at the start of the melt season. As ice is exposed, the sources $k_{\mathrm{I}}$ and $k_{\mathrm{II}}$, in addition to aerosols from melt-out $\left(k_{\mathrm{III}}\right)$, directly contribute to the aerosol amount on the ice surface. The accumulation is counteracted by a daily reduction fraction $r_{\text {ice }}$ of the order of 1 per mille per day when ice is exposed. In the snowpack all aerosols are conserved $\left(r_{\text {snow }}=0\right)$.

\subsection{Ice albedo}

Ice albedo is determined via the specific surface area of ice $\hat{S}$ and the reductions caused by dust and BC, as described in Goelles and Bøggild (2015). The dust concentration is converted into an equivalent $\mathrm{BC}$ concentration, and the albedo reduction is calculated with the parameterisation $d \alpha_{\iota, 1}$ by Gardner and Sharp (2010). A conversion from aerosol mass per area to ppm is required as the parameterisation is formulated in terms of $\mathrm{BC}$ concentration. This is done via the effective depth $d_{\text {eff }}$ representing the absorption length in ice. Only an active fraction $\mathcal{F}$ of the aerosols influences the ice albedo, while the remainder is concealed in cryoconite holes.

\subsection{Surface mass balance}

The surface mass balance is calculated with a simplified energy-balance model (e.g. Oerlemans, 2001) which is optimised for Greenland (Robinson et al., 2010, 2011; Goelles and Bøggild, 2015). It also includes a simple snowpack model and refreezing. If the snow depth exceeds $5 \mathrm{~m}$, the ice equivalent part is added to the ice thickness $H(x, t)$. The snow depth is also required for the surface albedo to distinguish between ice and snow. The snow albedo is divided into the two values $\alpha_{\text {snow, dry }}$ and $\alpha_{\text {snow, wet }}$. These values are kept constant throughout the experiments in order to separate the ice albedo effect.

\section{Experimental design and parameters}

\subsection{EISMINT and RCPs}

The experiments are based on the set-up of the European Ice Sheet Modelling Initiative (EISMINT Phase 2; Payne et al., 2000) combined with AR5 temperature projections for Representative Concentration Pathways (RCP; IPCC, 2013), with standard parameters listed in Table 1. These parameters are common for all simulations unless stated otherwise.

The EISMINT boundary conditions are symmetrical around $x_{\mathrm{su}}$ and roughly mimic conditions of a west-east cross section of Greenland. The simple, symmetric geometry is ideally suited as a test case for new methods with the additional benefit of ease of interpretation. In Goelles and Bøggild (2015) we introduced an annual temperature parameterisation with a trapezoidal shape:

$T= \begin{cases}T_{+} & t_{\bigcirc, \text { start }} \leq t \leq t_{\bigcirc, \text { end }} \\ t \varsigma-t_{\bigcirc, \text { start }} \varsigma+T_{+} & t<t_{\bigcirc, \text { start }} \\ -t \varsigma+t_{\bigcirc, \text { end }} \varsigma+T_{+} & t>t_{\bigcirc, \text { end }},\end{cases}$

where $T_{+}$is the mean summer temperature between $t_{\bigcirc}$,start and $t_{\bigcirc \text {,end. }}$. Based on the EISMINT set-up the temperature distribution in $x$ direction is

$T_{+}(x)=T_{+, \mathrm{su}}+S_{T} \sqrt{x-x_{\mathrm{su}}}$,

where $T_{+, \text {su }}$ is the minimum temperature located in at the summit and $S_{T}$ is the gradient with horizontal distance.

Temperature evolution scenarios are based on long-term projections until 2300 for the global annual mean surface temperature (Fig. 4). The RCPs are named after their expected radiative forcing in the year 2100 compared to preindustrial values. The four scenarios are RCP2.6, which is a mitigation scenario leading to low forcing, two stabilising scenarios (RCP4.5 and RCP6.0) and one scenario with 


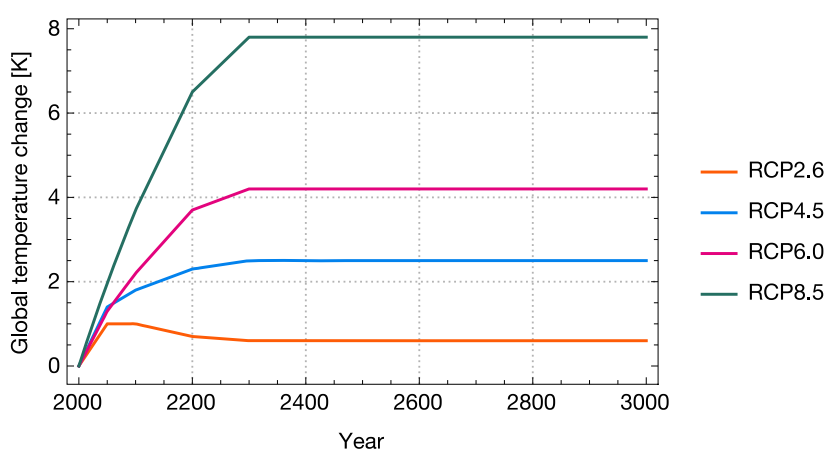

Figure 4. Global annual mean surface air temperature anomalies for different representative concentration pathways (IPCC, 2013; Table 12.2). After 2300 the temperature anomalies are kept constant.

very high concentrations (RCP8.5). The temperature anomalies are added each year to every grid cell.

The precipitation (see Fig. S1a in the Supplement) is kept on the same level for all RCP scenarios and corresponds to $0.5 \mathrm{ma}^{-1}$ ice equivalent in the accumulation zone, except for one experiment with an increase of $20 \%$ in precipitation $($ RCP $4.5+20 \%$ precip $\dagger)$.

The insolation at the top of the atmosphere (see Fig. S1b) is based on the calculations by Liou (2002) for $67^{\circ} \mathrm{N}$, in the centre-south of the Greenland ice sheet for which the EISMINT boundary conditions are roughly representative.

\subsection{Spin-up}

A spin-up model run acts as the common starting point for all experiments. The ice sheet after the spin-up is in steady state with the dust and $\mathrm{BC}$ concentrations computed over the whole domain. The spin-up starts at $-30 \mathrm{ka}$ and ends in the year 2000 with a resolution in $x$ of $25 \mathrm{~km}$ and 20 layers in $z$ direction. During the spin-up, the ice albedo is based on a specific surface area of $2 \mathrm{~cm}^{2} \mathrm{~g}^{-1}$ of ice of a density of 880 $\mathrm{kg} \mathrm{m}^{-3}$ and above (Dadic et al., 2013), equivalent to a clean ice albedo of 0.53 .

\section{Results}

\subsection{Spin-up}

It takes about 10000 years for the spin-up to reach equilibrium (see Fig. S2).

The simulated englacial aerosol concentration, depositional $x$ and time are shown in Fig. 5. Of those quantities, the depositional time $t_{\mathrm{d}}$ (panel d) is the most important one as the englacial $\mathrm{BC}$ and dust concentrations are inferred from it (Eq. 1). Ice older than $-20 \mathrm{ka}$ can only be found at the very bottom and not close to the surface, which indicates that the spin-up is sufficiently long.

Figure 6 shows surface values of the same quantities as in Fig. 5. At each time step, the values are joined together, which results in graphs showing the surface evolution of the respective quantities over the whole period. The ice sheet expands in the first few thousand years until a dynamic equilibrium is reached, as can be seen in the widening of the surface values in the upper sections of the graphs.

The high BC concentrations during the period 1850-1950 are indicated in light green in Figs. 5d and 6d. This period is short compared to the whole spin-up and is visible as a thin light-green stripe close to the surface in the cross section (Fig. 5b) and in the bottom part of the time series plot (Fig. 6b). Most of the ice was deposited before 1850, and therefore most parts of the ice have a $0 \mathrm{BC}$ concentration.

The sequence of peaks in the dust time series can be seen in Fig. 6a as a sequence of red stripes, indicating high concentrations. The stripes are first visible in the accumulation area in the centre and later in the ablation zone on the sides. The low Holocene values dominate after $-10 \mathrm{ka}$, and dust concentrations are only high in the outermost grid cells on each site. This is the region where ice from the last glacial reaches the surface (Fig. 6d).

\subsection{Ice sheet volume evolution}

Results of the experiments driven by the four RCP scenarios with (dashed lines) and without (solid lines) aerosols from the year 2000 to 3000 are shown in Fig. 7. In general, the ice sheet is thinner everywhere in the year 3000 when dust and $\mathrm{BC}$ are considered (panel b). The main height differences (panel c) are located at the margin. This is a result of the lower annual SMB (panel d), which in general is lower in the ablation zone when aerosols are considered. Panel e shows the volume change relative to the constant climate/noaerosols run. The inset shows the period with transient temperatures until 2300 in more detail. Panel $f$ displays the volume change of each RCP scenario when aerosols are considered relative to the no-aerosols run. The higher the temperatures, the more influential are the aerosols.

In the year 2100, the volume change relative to no aerosols (Fig. 7f) is below one percent for all scenarios. For RCP8.5 it is $-0.26 \%$ and for RCP4.5-0.16\%. In the year 2300 , the influence of aerosols for RCP 2.6 is $-0.08 \%$, for RCP $4.5-0.68 \%$, for RCP6.0 $-1.05 \%$ and for RCP $8.5-1.65 \%$. After the year 2300, the temperatures remain unchanged at the 2300 level, and the ice dynamics still responds to the increased melt at the margin, and in addition aerosols continue to accumulate and fade away.

In the year 3000, the ice sheet volume is $1.46 \%$ smaller for RCP4.5 and $7.61 \%$ smaller for RCP8.5 when aerosols are considered.

\subsection{RCP4.5 in more detail}

The evolution of the RCP4.5 simulation with aerosols (RCP4.5 aerosols) is now presented in more detail. Figure 8 shows the ice albedo time series, in which the low values 

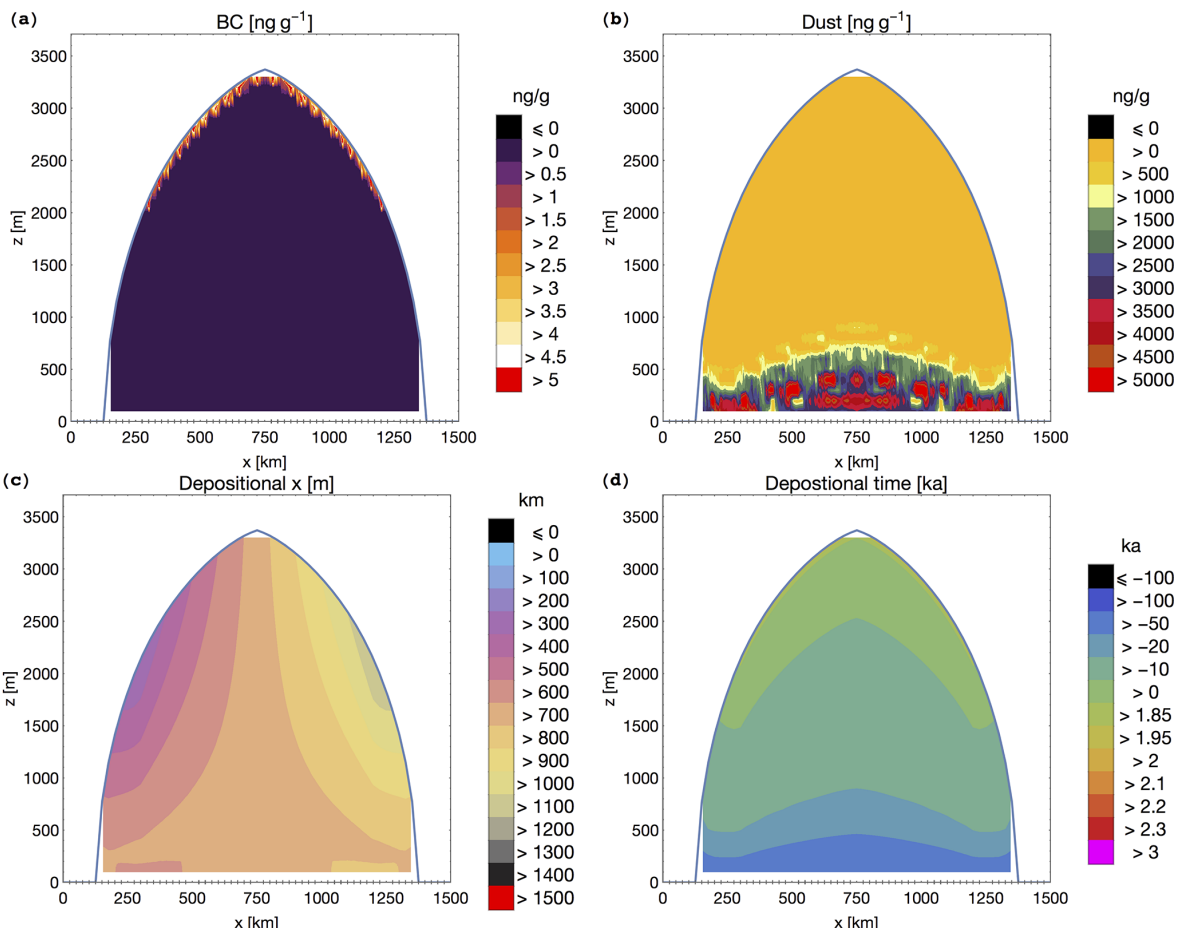

Figure 5. Cross section of the spin-up ice sheet in the year 2000: (a) englacial black carbon concentration, (b) dust concentration, (c) depositional $x$ (provenance) and (d) depositional time (where $2 \mathrm{ka}$ is the year $2000 \mathrm{AD}$ ).

(a)
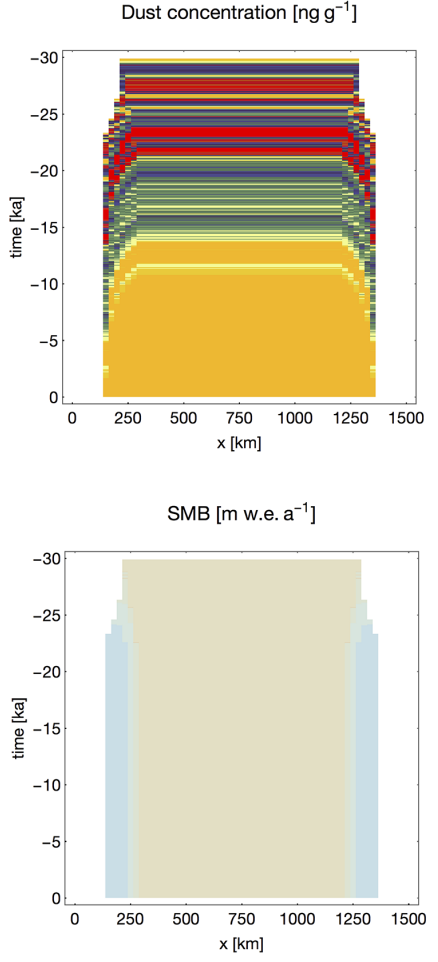

(b)

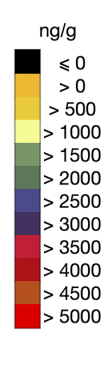

mwe.

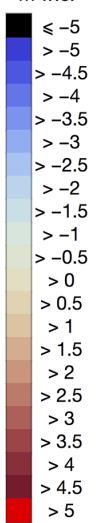

(d)
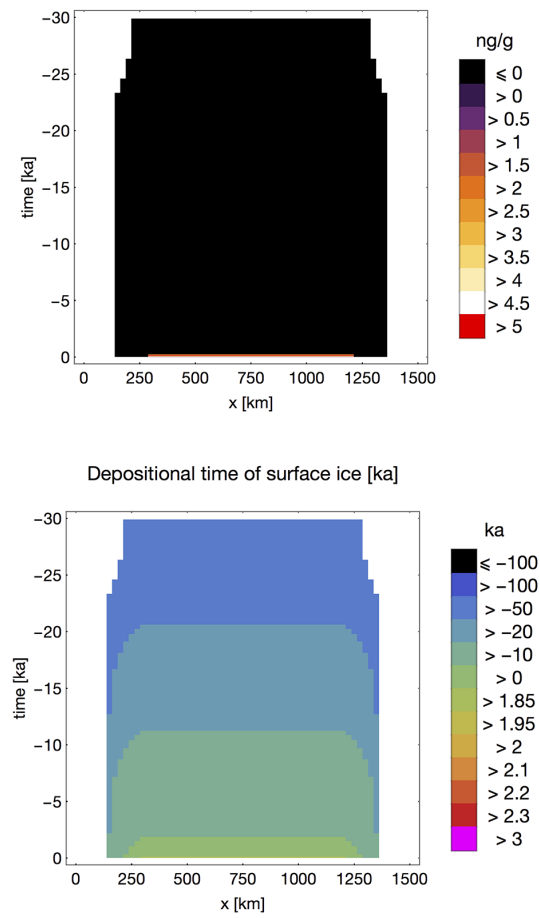

Figure 6. Time series of the surface values of (a) englacial dust, (b) englacial BC, (c) surface mass balance and (d) time of deposition. The vertical axis shows time with the start of simulation at the top. 

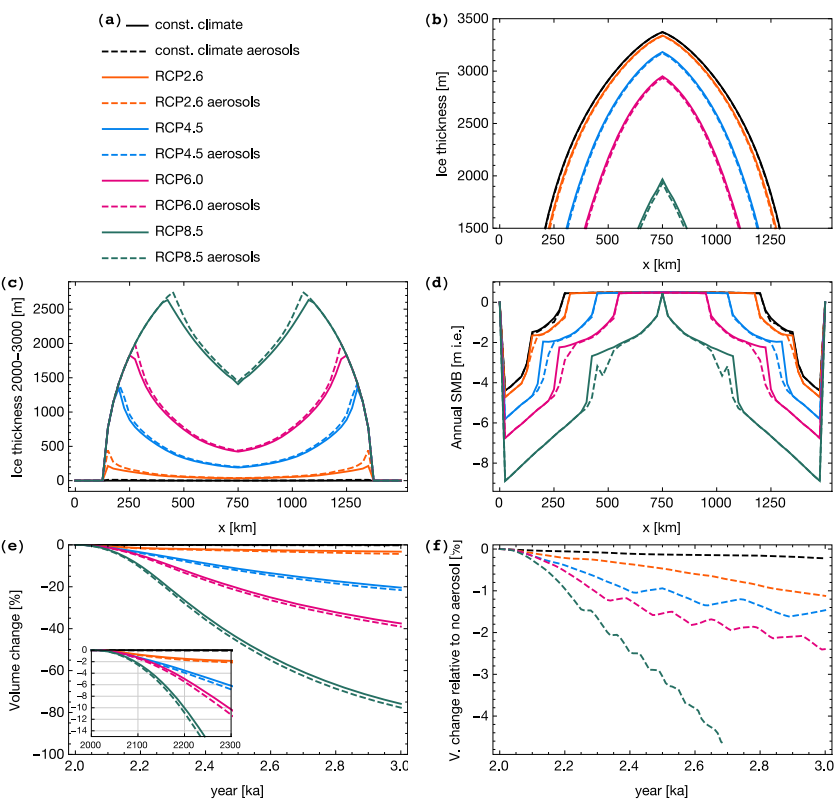

Figure 7. Results of the simulations driven by the representative concentration pathways: (a) common curve styles, (b) ice thickness in the year 3000, (c) elevation difference compared to the constant climate run, (d) SMB in the year 3000, (e) relative volume change compared to the constant climate/no-aerosols scenario (inset: detailed plot for the period until 2300) and (f) volume change due to the inclusion of aerosols.

at the very margin are caused by dust (see Fig. 9a and c). The low values below 0.40 close the accumulation zone are caused by BC, as the younger ice there contains BC from the period with higher concentrations. Until 2300 black carbon lowers the ice albedo of up to three grid points, and later on only one is affected.

The main part of the ablation zone in Fig. 9 has low values of aerosol concentrations. This is because the englacial BC is 0 when the age of the ice is younger than at the start of the time series but older than glacial ice with high dust concentrations. Therefore, the BC content at the surface is only due to the atmospheric deposition which is low (Goelles and $\mathrm{B} \emptyset \mathrm{g}$ gild, 2015). The surface amount of BC accumulates to just $200 \mathrm{ng} \mathrm{m}^{-2}$. The surface content of dust contains, besides the atmospheric signal, melt-out of the low englacial concentration during the Holocene of $20 \mathrm{ng} \mathrm{g}^{-1}$ and accumulates to $0.4 \mathrm{~g} \mathrm{~m}^{-2}$. The combined effect of dust and BC causes a constant albedo reduction of about $1.0 \%$. This causes a lower SMB in the central part of the ablation zone when aerosols are considered (Fig. 7).

Irregular peaks in the aerosol concentration can be seen in the englacial concentrations in panels a and $b$. Those peaks cause also higher amounts of aerosols at the surface due to the slow loss of aerosols at the surface. Nevertheless, over millennial time scales, the prolonged residence time of some

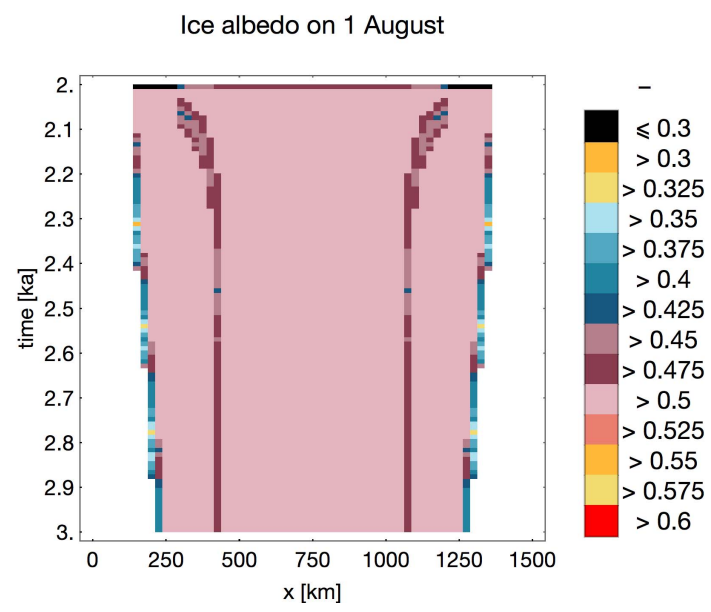

Figure 8. Simulation RCP4.5 aerosols: ice albedo on 1 August.

decades is comparably short. This can be seen for example in Fig. $9 b$ and $d$ after the year 2550.

Figure 10 shows the volume change relative to the RCP4.5 simulation without aerosols, and how the results depend on different parameter values. The blue thick line is the same as in Fig. 7f. The simulations marked with $\dagger$ are compared to another reference. Run RCP4.5 mound aerosol $\dagger$ is compared to a run with mound topography and RCP4.5 conditions but no aerosols. RCP4.5 $+20 \%$ precip $\dagger$ is compared to a simulation with $20 \%$ more precipitation and RCP4.5 conditions but no aerosols. Simulation RCP4.5 aerosols $\dagger$ is compared to a reference for which the ice albedo already considers the $1.0 \%$ reduction mentioned above. Experiment RCP4.5 mound aerosol $\dagger$ uses $500 \mathrm{~m}$ mounds from the EISMINT (experiment $\mathrm{K}$ ) set-up, and the volume change is calculated from a spin-up with these mounds. The effect of aerosols is slightly lower during the simulation but very close to the original simulation in the year 3000 .

The highest impact of aerosols was reached with an active fraction $\mathcal{F}$ of 0.8 , closely followed by an effective depth $d_{\text {eff }}$ of $3 \mathrm{~m}$. Both parameters determine how much aerosols influence the ice albedo.

Considering only BC (RCP4.5 BC only) leads to $0.42 \%$ and dust alone to $1.16 \%$ additional ice sheet volume loss in the year 3000 compared to the simulation RCP4.5 without aerosols. Therefore, dust is responsible for the major part of ice sheet loss.

\section{Discussion}

\subsection{The effect of aerosols on ice volume}

The additional ice loss caused by aerosols increases nonlinearly with temperature (Fig. 7e and f). The non-linearity is caused by the relationship between BC concentration and albedo reduction (Fig. S4) as well as a positive feedback 
(a)
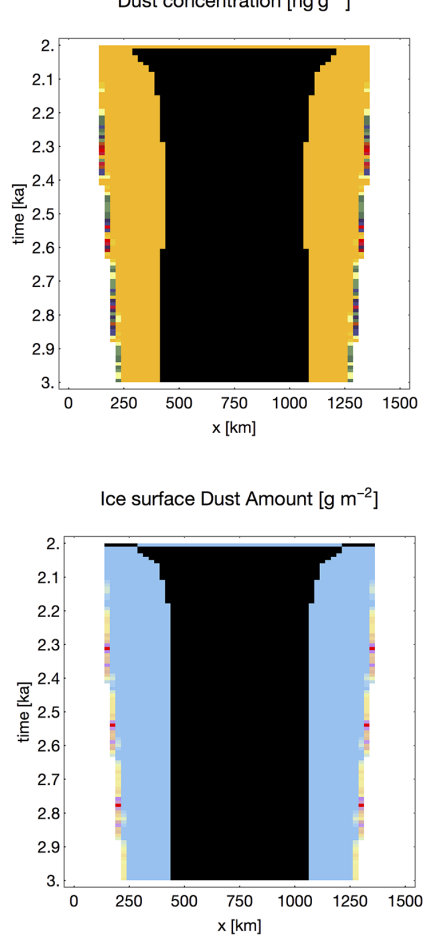

(e)

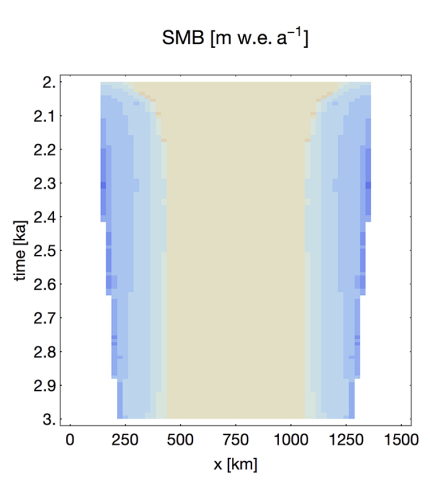

(b)

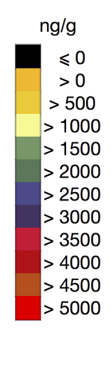

$\mathrm{g} m^{-2} \quad(\mathbf{d})$

(d)
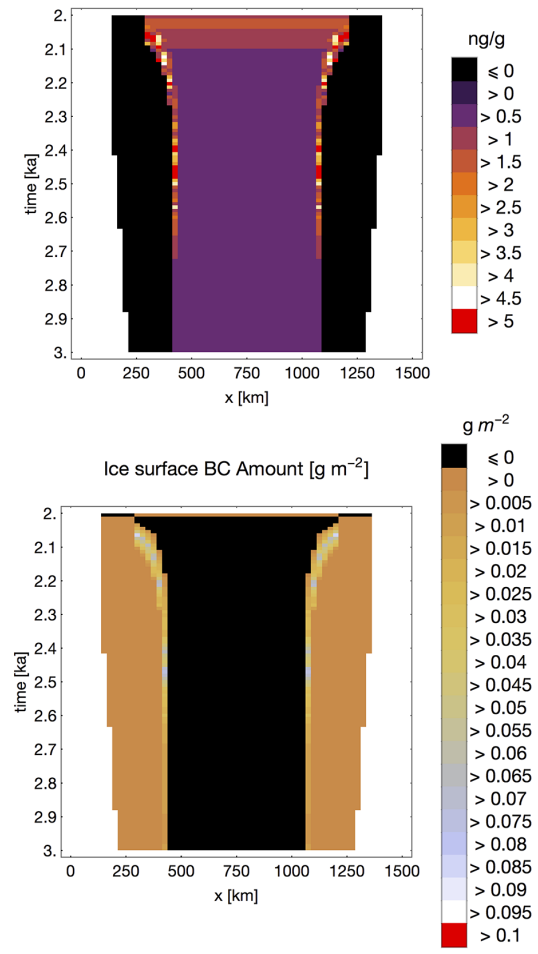

(f)

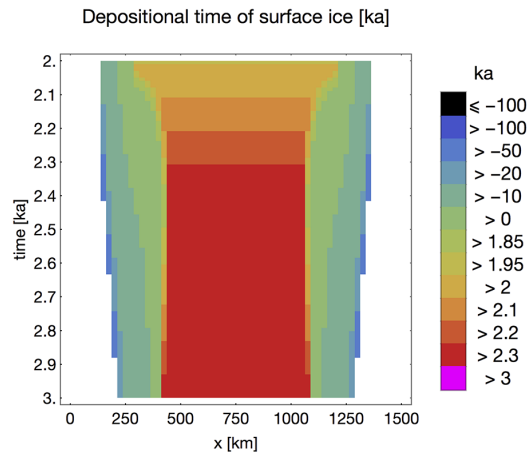

Figure 9. Time series of the RCP 4.5 scenario including aerosols: (a) englacial dust, (b) BC concentrations, (c and d) respective surface amount on 1 August, (e) surface mass balance and (f) depositional time of ice at the surface.

between ice melt and aerosol accumulation. We did not include other feedbacks such as the elevation feedback and the albedo feedback to temperature. There is a weak negative elevation feedback included due to the parameterisation of the transmissivity (Robinson et al., 2010). Otherwise, the elevation and albedo feedbacks are positive, which further enhances melt. Due to this, and since we used global temperature anomalies for the simulations, the strength of the aerosol effect found in this study is expected to be a lower boundary.

The two BC scenarios (RCP4.5 BC future 0 and RCP4.5 $\mathrm{BC}$ future3) result in a similar evolution as the standard setup. This is a consequence of the time lag between aerosol deposition and melt-out at the ablation zone. Only the highest grid point in the ablation zone is affected by aerosols deposited after 2000 (see Fig. 9f). Therefore the effect of different $\mathrm{BC}$ and also dust emissions from the year 2000 onwards is limited until the year 3000. Nevertheless, BC and dust deposition has a direct effect on snow albedo and a long-term effect on ice albedo.

Ice albedo is sensitive to the small addition of impurities when the ice is clean (Fig. S4a). If the same amount of impurities is added to an already dark ice surface, the additional effect is weaker as compared to a clean surface. This could lead to an overestimation of the effect, whereas the missing feedbacks can lead to an underestimation; which effects 


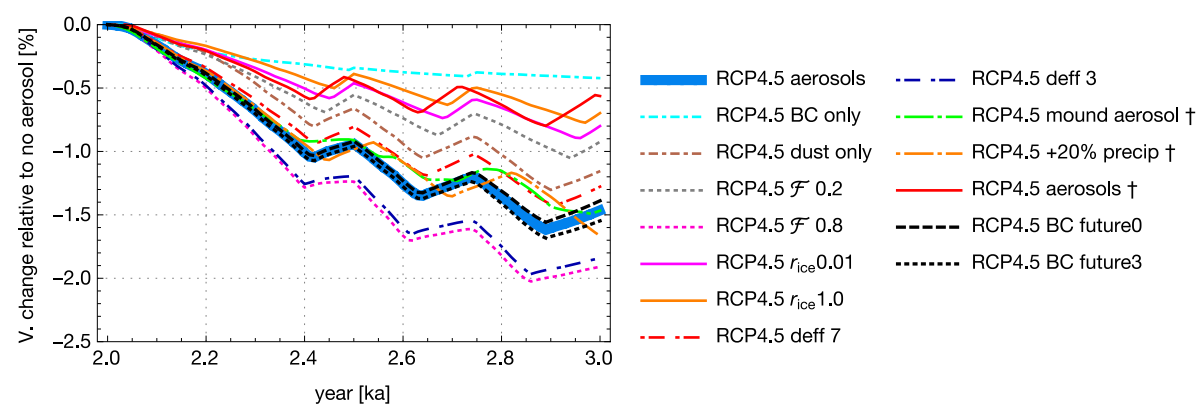

Figure 10. Simulations with RCP4.5 forcing: ice sheet volume change with aerosols (for different parameter settings) compared to the standard RCP4.5 run without aerosols. Simulations marked with a $\dagger$ are compared to a different reference; see main text.

dominate requires additional research. Nevertheless, the nonlinear nature of the effect and the amplification due to rising temperatures presented in this study remain.

\subsection{Assumptions, simplifications and uncertainties}

The magnitude and non-linear dependence on future temperature of the aerosol effect were shown with a new model framework and applied to a simplified geometry experiment. Here we discuss if and how the assumptions and simplifications could have lead to an overestimation of the effect.

The experiments were performed using a flat bedrock topography; however, the effect of $500 \mathrm{~m}$ high mounds was also investigated (Fig. 10, run RCP4.5 mound aerosol $\dagger$ ). The effect was sometimes weaker but very similar at the end of the simulation. The topography of the bedrock below the Greenland ice sheet is more complicated than sinusoidal mounds (Bamber et al., 2013); nevertheless, the effect remained even though the timing when aerosols emerge is influenced by the topography.

The ice dynamics module was compared to an analytical solution (Cuffey and Paterson, 2010). Close to the ice margin the shallow-ice approximation employed can be violated, and thus velocities can be computed incorrectly when the surface slope is steep (e.g. Ahlkrona et al., 2013; Greve and Blatter, 2009). This typically occurs in areas where the ice sheet reaches the coast and calving is present. However, in our case, we have pronounced ablation zones on both sides of the two-dimensional domain (Fig. S3). Therefore, the simulated ice sheet never reaches the boundaries of the domain and maximal surface slopes at the ice margin are just around $1^{\circ}$, which is well within acceptable limits for the validity of the shallow-ice approximation.

The tracer transport, which is used to derive the englacial aerosol concentration, influences the rate of melt-out and therefore the amount of accumulated aerosols on the ice surface. The accuracy of the module depends on the velocities and the numerics of the transport scheme. Here we use a first-order scheme which was found to deliver different results in the ablation zone (Goelles et al., 2014). Nevertheless the calculated ages are comparable to radio stratigraphy from Greenland (MacGregor et al., 2015) as the horizon of the boundary between Holocene and glacial ice is at similar depths.

The aerosol time series of mineral dust and $\mathrm{BC}$ have a more direct effect on the results. They determine the englacial concentration, which directly influences the ice albedo and determines the amount of melt-out. We assumed that the aerosol concentration solely depends on the age of the ice because distant ice cores correlate well (Bigler, 2012).

However, if this were not the case, and aerosols were deposited in smaller patches rather than uniformly, then they would also be released in smaller areas in the ablation zone. Owing to the reduced response when aerosols are added to an already dark surface (Fig. S4), the effect of aerosols would then be smaller.

Nevertheless, close to the ELA the surrounding tundra could contribute locally to the englacial dust concentration (Wientjes et al., 2012). As mentioned in Goelles and Bøggild (2015) there might be a "threshold elevation" up to which local dust contributes.

$\mathrm{BC}$ concentration peaks due to forest fires (Fig. 3) are only available between 1788 and 2000. Also, dust ice core data of the Holocene are not available. Since the central part of the ablation zone has its origin in the Holocene, the englacial aerosols consist of only dust which has a low and constant value. This is the cause for the slight decrease of albedo in the centre part of the ablation zone.

The aerosol accumulation determines the amount of aerosols which darken the ice surface and therefore plays an important role in the overall estimation of the effect. The direct input from the atmosphere $\left(k_{\mathrm{II}}\right)$ was constant in this study, and the input from the tundra was 0 . This is most likely true for BC as local sources on Greenland are negligible. Below the "threshold elevation", dust from the surrounding tundra might contribute significantly. The dust amount at the margin is already large due to melt-out of glacial dust. Therefore, an additional amount of dust from the tundra has a smaller effect as the surface is already dark (Fig. S4). Beside the input, the daily reduction on ice $r_{\text {ice }}$ determines the surface amount. This parameter was found to be of the order 
of 1 per mille per day, which is comparable with measurements (Goelles and Bøggild, 2015). Under warming scenarios, the daily reduction might increase with increased surface run-off due to meltwater and rainfall, which would have a stabilising effect that is currently not captured.

Under recent conditions, the amount of meltwater run-off is typically 1 to 2 magnitudes higher than summer rainfall. Therefore, even with more rainfall during summer in the future, the potential increase of the daily reduction will most likely be determined by the meltwater run-off.

The relationship of aerosols and ice albedo depends on the specific surface area of ice, englacial concentration, the amount at the surface, the conversion to $\mathrm{BC}$ concentration and the darkening parameterisation as well as the active fraction $\mathcal{F}$. The conversion to concentration is necessary because of the formulation of the darkening parameterisation and depends on the effective depth $d_{\text {eff. }}$ The value is based on the absorption length in ice which varies greatly with wavelength (Warren and Brandt, 2008). The conversion of mass per area to concentration (ppm) would not be necessary if an ice albedo reduction parameterisation based on mass of BC per area existed. Also, the active fraction $\mathcal{F}$ is similarly powerful as the effective depth and not well constrained. The parameter lumps together all surface processes which keep aerosols from darkening the ice surface. This part of the model is based on a lower level of understanding and yet causes a wide spread in the outcome; therefore it requires more attention (see Goelles and Bøggild, 2015; Hodson, 2014). Nevertheless, even at a low active fraction or a high effective depth the effect remains (Fig. 10).

The surface mass balance determines the snow depth, which governs how long ice is exposed and the amount of outcropping aerosols $\left(k_{\mathrm{III}}\right)$. The time span of ice exposure is important for the actual effect of ice albedo and, secondly, for the period of aerosol reduction $\left(r_{\text {ice }, n}\right)$. Especially the longwave radiation coefficient $\lambda$ is very influential as it scales the temperature dependence of melt (Fig. S4). Nevertheless, tests with data from western Greenland showed results comparable to observations (Goelles and Bøggild, 2015).

Overall the magnitude of the effect of aerosols depends on all the parts discussed, but even though limitations exist the effect is intuitively understandable. More ice melt causes an increase of outcropping aerosols, which have a long residence time at the surface. These aerosols darken the ice surface, which further enhances ice melt. The presented model components capture the main effect, while the exact timing when and where aerosols emerge is harder to achieve.

\section{Conclusions}

We tested the ice volume response to darker ice in the ablation zone caused by accumulation of dust and black carbon. We introduced a new model framework which includes advection, melt-out and accumulation of aerosols and its dark- ening effect on the surface mass balance. The response of the ice volume to the aerosols depends non-linearly on the future temperature because of a positive feedback between ice melt and aerosol melt-out which is disproportionally larger in warmer climate scenarios. The exact timing when and where darkening occurs is difficult to achieve; however, the overall effect is captured with the presented framework.

In order to isolate the effect of ice albedo, we kept the snow albedo unaffected by impurities. A 0.01 lower fresh snow albedo causes a decrease of $27 \mathrm{Gta}^{-1}$ of the total surface mass balance for the Greenland ice sheet (Dumont et al., 2014). Therefore the combined effect of impurities on snow and ice albedo is significantly larger then the ice albedo effect alone.

The effect of black carbon from the industrial revolution was significant and will have an effect for a long time to come. Currently, Asian black carbon emissions are rising which could lead, besides to the darkening of snow, to darker ice via direct deposition and over long time scales via ice flow.

The presented principles are not just limited to Greenland in the future but could also be applied to palaeo-climatic studies, detailed studies for alpine glaciers or the termination of the little ice age (Painter et al., 2013).

We investigated the response under the RCP4.5 scenario in more detail and tested the sensitivity to several parameters. Considering that the temperatures in the Arctic rise higher than the global mean and the elevation and ice albedo feedbacks were not considered, the estimated effect can be seen as a lower boundary estimate. The presented simulations were based on a simplified geometry in two dimensions; nevertheless the age structure and overall system resembles the Greenland ice sheet. The presented simulations should not be seen as forecasts but emphasise the importance of the effect.

\section{The Supplement related to this article is available online at doi:10.5194/tc-9-1845-2015-supplement.}

Acknowledgements. We thank the editor J. L. Bamber, the reviewer $\mathrm{X}$. Fettweis and an anonymous reviewer for their helpful comments. This publication is contribution number 64 of the Nordic Centre of Excellence SVALI, "Stability and Variations of Arctic Land Ice", funded by the Nordic Top-level Research Initiative (TRI). R. Greve was supported by MEXT Japan (Japanese Ministry of Education, Culture, Sports, Science and Technology) through the Green Network of Excellence (GRENE) Arctic Climate Change Research Project "Rapid Change of the Arctic Climate System and its Global Influences" (2011-2016). 


\section{References}

Ahlkrona, J., Kirchner, N., and Lötstedt, P.: A numerical study of scaling relations for non-newtonian thin-film flows with applications in ice sheet modelling, Q. J. Mech. Appl. Math., 66, 417435, doi:10.1093/qjmam/hbt009, 2013.

Bamber, J. L., Griggs, J. A., Hurkmans, R. T. W. L., Dowdeswell, J. A., Gogineni, S. P., Howat, I., Mouginot, J., Paden, J., Palmer, S., Rignot, E., and Steinhage, D.: A new bed elevation dataset for Greenland, The Cryosphere, 7, 499-510, doi:10.5194/tc-7-499-2013, 2013.

Bauer, S. E., Bausch, A., Nazarenko, L., Tsigaridis, K., Xu, B., Edwards, R., Bisiaux, M., and McConnell, J.: Historical and future black carbon deposition on the three ice caps: ice core measurements and model simulations from 1850 to 2100 , J. Geophys. Res.-Atmos., 118, 7948-7961, doi:10.1002/jgrd.50612, 2013.

Bigler, M.: New aerosol measurements from the Greenland NEEM ice core, in: EGU General Assembly Conference Abstracts, 2227 April 2012, Vienna, Austria, 5780 pp., 2012.

Biscaye, P. E., Grousset, F. E., Revel, M., van der Gaast, S., Zielinski, G. A., Vaars, A., and Kukla, G.: Asian provenance of glacial dust (stage 2) in the Greenland Ice Sheet Project 2 Ice Core, Summit, Greenland, J. Geophys. Res.-Oceans, 102, 26765-26781, doi:10.1029/97JC01249, 1997.

Bøggild, C. E., Oerter, H., and Tukiainen, T.: Increased ablation of Wisconsin ice in eastern north Greenland: observations and modelling, Ann. Glaciol., 23, 144-148, 1996.

Bøggild, C. E., Brandt, R., Brown, K., and Warren, S. G.: The ablation zone in northeast Greenland: ice types, albedos and impurities, J. Glaciol., 56, 101-113, doi:10.3189/002214310791190776, 2010.

Bond, T. C., Doherty, S. J., Fahey, D. W., Forster, P. M., Berntsen, T., DeAngelo, B. J., Flanner, M. G., Ghan, S., Kaercher, B., Koch, D., Kinne, S., Kondo, Y., Quinn, P. K., Sarofim, M. C., Schultz, M. G., Schulz, M., Venkataraman, C., Zhang, H., Zhang, S., Bellouin, N., Guttikunda, S. K., Hopke, P. K., Jacobson, M. Z., Kaiser, J. W., Klimont, Z., Lohmann, U., Schwarz, J. P., Shindell, D., Storelvmo, T., Warren, S. G., and Zender, C. S.: Bounding the role of black carbon in the climate system: a scientific assessment, J. Geophys. Res.Atmos., 118, 5380-5552, doi:10.1002/jgrd.50171, 2013.

Bougamont, M., Bamber, J. L., and Greuell, W.: A surface mass balance model for the Greenland Ice Sheet, J. Geophys. Res., 110, F04018, doi:10.1029/2005JF000348, 2005.

Clarke, G. and Marshall, S. J.: Isotopic balance of the Greenland Ice Sheet: modelled concentrations of water isotopes from $30000 \mathrm{BP}$ to present, Quaternary Sci. Rev., 21, 419-430, 2002.

Clarke, G., Lhomme, N., and Marshall, S. J.: Tracer transport in the Greenland ice sheet: three-dimensional isotopic stratigraphy, Quaternary Sci. Rev., 24, 155-171, doi:10.1016/j.quascirev.2004.08.021, 2005.

Cuffey, K. M. and Paterson, W. S. B.: The Physics of Glaciers, 4th edn., Academic Press, Burlington, Oxford, 2010.

Dadic, R., Mullen, P. C., Schneebeli, M., Brandt, R., and Warren, S. G.: Effects of bubbles, cracks, and volcanic tephra on the spectral albedo of bare ice near the Transantarctic Mountains: Implications for sea glaciers on Snowball Earth, J. Geophys. Res.Earth, 118, 1658-1676, doi:10.1002/jgrf.20098, 2013.

Dumont, M., Brun, E., Picard, G., Michou, M., Libois, Q., Petit, J. R., Geyer, M., Morin, S., and Josse, B.: Contribution of light-absorbing impurities in snow to Greenland's darkening since 2009, Nat. Geosci., 7, 509-512, doi:10.1038/ngeo2180, 2014.

Enderlin, E. M., Howat, I. M., Jeong, S., Noh, M. J., Angelen, J. H., and Van den Broeke, M. R.: An improved mass budget for the Greenland ice sheet, Geophys. Res. Lett., 41, 866-872, doi:10.1002/(ISSN)1944-8007, 2014.

Gardner, A. and Sharp, M.: A review of snow and ice albedo and the development of a new physically based broadband albedo parameterization, J. Geophys. Res., 115, F01009, doi:10.1029/2009JF001444, 2010.

Goelles, T. and Bøggild, C. E.: Albedo reduction caused by black carbon and dust accumulation: a quantitive model applied to the western margin of the Greenland ice sheet, The Cryosphere Discuss., 9, 1345-1381, doi:10.5194/tcd-9-1345-2015, 2015.

Goelles, T., Grosfeld, K., and Lohmann, G.: Semi-Lagrangian transport of oxygen isotopes in polythermal ice sheets: implementation and first results, Geosci. Model Dev., 7, 1395-1408, doi:10.5194/gmd-7-1395-2014, 2014.

Goelzer, H., Huybrechts, P., Fürst, J. J., Nick, F. M., Andersen, M. L., Edwards, T. L., Fettweis, X., Payne, A. J., and Shannon, S.: Sensitivity of Greenland ice sheet projections to model formulations, J. Glaciol., 59, 733-749, doi:10.3189/2013JoG12J182, 2013.

Greve, R.: Relation of measured basal temperatures and the spatial distribution of the geothermal heat flux for the Greenland ice sheet, Ann. Glaciol., 42, 424-432, doi:10.3189/172756405781812510, 2005.

Greve, R. and Calov, R.: Comparison of numerical schemes for the solution of the ice-thickness equation in a dynamic/thermodynamic ice-sheet model, J. Comput. Phys., 179, 649-664, doi:10.1006/jcph.2002.7081, 2002.

Greve, R. and Blatter, H.: Dynamics of Ice Sheets and Glaciers, Springer, Dordrecht, 287 pp., 2009.

Hodson, A. J.: Understanding the dynamics of black carbon and associated contaminants in glacial systems, Wiley Interdisciplinary Reviews: Water, 1, 141-149, doi:10.1002/wat2.1016, 2014.

IPCC: Climate Change 2013: The Physical Science Basis: Working Group I Contribution to the Fifth Assessment Report of the Intergovernmental Panel on Climate Change, Cambridge University Press, Cambridge, doi:10.1017/CBO9781107415324.004, 2013.

Lei, Y., Zhang, Q., He, K. B., and Streets, D. G.: Primary anthropogenic aerosol emission trends for China, 1990-2005, Atmos. Chem. Phys., 11, 931-954, doi:10.5194/acp-11-931-2011, 2011.

Lhomme, N.: Modelling water isotopes in polar ice sheets, $\mathrm{PhD}$ thesis, The University of British Columbia, 172 pp., 2004.

Lhomme, N., Clarke, G., and Marshall, S. J.: Tracer transport in the Greenland Ice Sheet: constraints on ice cores and glacial history, Quaternary Sci. Rev., 24, 173-194, doi:10.1016/j.quascirev.2004.08.020, 2005.

Liou, K. N.: An Introduction to Atmospheric Radiation, Volume 84, International Geophysics, 2nd edn., Academic Press, San Diego and London, 583 pp., 2002.

Lu, Z., Zhang, Q., and Streets, D. G.: Sulfur dioxide and primary carbonaceous aerosol emissions in China and India, 1996-2010, Atmos. Chem. Phys., 11, 9839-9864, doi:10.5194/acp-11-98392011, 2011.

MacGregor, J. A., Fahnestock, M. A., Catania, G. A., Paden, J. D., Gogineni, S. P., Young, S. K., Rybarski, S. C., Mabrey, A. N., 
Wagman, B. M., and Morlighem, M.: Radiostratigraphy and age structure of the Greenland Ice Sheet, J. Geophys. Res.-Earth, 120, 212-241, doi:10.1002/2014JF003215, 2015.

McConnell, J., Edwards, R., Kok, G., Flanner, M., Zender, C. S., Saltzman, E., Banta, J., Pasteris, D., Carter, M., and Kahl, J.: 20th-century industrial black carbon emissions altered arctic climate forcing, Science, 317, 1381, doi:10.1126/science.1144856, 2007.

Mernild, S. H., Liston, G. E., Hiemstra, C. A., and Christensen, J. H.: Greenland Ice Sheet surface mass-balance modeling in a 131-yr perspective, 1950-2080, J. Hydrometeorol., 11, 3-25, doi:10.1175/2009JHM1140.1, 2010.

Oerlemans, J.: Glaciers and Climate Change, A. A. Balkema Publishers, Lisse, Exton, PA, 148 pp., 2001.

Painter, T. H., Flanner, M. G., Kaser, G., Marzeion, B., VanCuren, R. A., and Abdalati, W.: End of the Little Ice Age in the Alps forced by industrial black carbon, P. Natl. Acad. Sci. USA, 110, 15216-15221, doi:10.1073/pnas.1302570110, 2013.

Payne, A., Huybrechts, P., Abe-Ouchi, A., Calov, R., Fastook, J., Greve, R., Marshall, S. J., Marsiat, I., Ritz, C., Tarasov, L., and Thomassen, M.: Results from the EISMINT model intercomparison: the effects of thermomechanical coupling, J. Glaciol., 46, 227-238, doi:10.3189/172756500781832891, 2000.

Rae, J. G. L., Aðalgeirsdóttir, G., Edwards, T. L., Fettweis, X., Gregory, J. M., Hewitt, H. T., Lowe, J. A., LucasPicher, P., Mottram, R. H., Payne, A. J., Ridley, J. K., Shannon, S. R., van de Berg, W. J., van de Wal, R. S. W., and van den Broeke, M. R.: Greenland ice sheet surface mass balance: evaluating simulations and making projections with regional climate models, The Cryosphere, 6, 1275-1294, doi:10.5194/tc-6-1275-2012, 2012.

Reeh, N., Oerter, H., Letréguilly, A., Miller, H., and Hubberten, H.W.: A new, detailed ice-age oxygen-18 record from the ice-sheet margin in central West Greenland, Global Planet. Change, 4, 373-383, doi:10.1016/0921-8181(91)90003-F, 1991.

Robinson, A., Calov, R., and Ganopolski, A.: An efficient regional energy-moisture balance model for simulation of the Greenland Ice Sheet response to climate change, The Cryosphere, 4, 129144, doi:10.5194/tc-4-129-2010, 2010.

Robinson, A., Calov, R., and Ganopolski, A.: Greenland ice sheet model parameters constrained using simulations of the Eemian Interglacial, Clim. Past, 7, 381-396, doi:10.5194/cp-7-381-2011, 2011.

Ruth, U.: Dust concentration in the NGRIP ice core, doi:10.1594/PANGAEA.587836, Supplement to: Ruth, U., Bigler, M., Röthlisberger, R., Siggaard-Andersen, M.-L., Kipfstuhl, J., Goto-Azuma, K., Hansson, M. E., Johnsen, S. J., Lu, H., and Steffensen, J. P.: Ice core evidence for a very tight link between North Atlantic and east Asian glacial climate, Geophys. Res. Lett., 34, L03706, doi:10.1029/2006GL027876, 2007.
Steffensen, J. P.: The size distribution of microparticles from selected segments of the Greenland Ice Core Project ice core representing different climatic periods, J. Geophys. Res.-Oceans, 102, 26755-26763, doi:10.1029/97JC01490, 1997.

Stibal, M., Šabacká, M., and Žárský, J.: Biological processes on glacier and ice sheet surfaces, Nat. Geosci., 5, 771-774, doi:10.1038/ngeo1611, 2012.

Takeuchi, N., Nagatsuka, N., Uetake, J., and Shimada, R.: Spatial variations in impurities (cryoconite) on glaciers in northwest Greenland, B. Glaciol. Res., 32, 85-94, doi:10.5331/bgr.32.85, 2014.

Tedesco, M., Fettweis, X., Van den Broeke, M. R., Van de Wal, R. S. W., Smeets, C. J. P. P., Van de Berg, W. J., Serreze, M. C., and Box, J. E.: The role of albedo and accumulation in the 2010 melting record in Greenland, Environ. Res. Lett., 6, 014005, doi:10.1088/1748-9326/6/1/014005, 2011.

van Angelen, J. H., Lenaerts, J. T. M., Lhermitte, S., Fettweis, X., Kuipers Munneke, P., van den Broeke, M. R., van Meijgaard, E., and Smeets, C. J. P. P.: Sensitivity of Greenland Ice Sheet surface mass balance to surface albedo parameterization: a study with a regional climate model, The Cryosphere, 6, 1175-1186, doi:10.5194/tc-6-1175-2012, 2012.

Warren, S. G. and Wiscombe, W. J.: A model for the spectral albedo of snow. II: Snow containing atmospheric aerosols, J. Atmos. Sci., 37, 2734-2745, 1980.

Warren, S. G. and Brandt, R.: Optical constants of ice from the ultraviolet to the microwave: a revised compilation, J. Geophys. Res.-Atmos., 113, D14220, doi:10.1029/2007JD009744, 2008.

Wientjes, I. G. M., Van de Wal, R. S. W., Schwikowski, M., Zapf, A., Fahrni, S., and Wacker, L.: Carbonaceous particles reveal that Late Holocene dust causes the dark region in the western ablation zone of the Greenland ice sheet, J. Glaciol., 58, 787794, doi:10.3189/2012JoG11J165, 2012.

Wolfram Research, Inc.: Mathematica, Champaign, Illinois, 2014.

Yallop, M. L., Anesio, A. M., Perkins, R. G., Cook, J., Telling, J., Fagan, D., MacFarlane, J., Stibal, M., Barker, G., Bellas, C., Hodson, A., Tranter, M., Wadham, J., and Roberts, N. W.: Photophysiology and albedo-changing potential of the ice algal community on the surface of the Greenland ice sheet, ISME J., 6, 2302-2313, doi:10.1038/ismej.2012.107, 2012. 